\title{
The chemical composition and inhibitory action of Punica granatum (L.) extracts against Candida spp.: A brief review
}

\author{
Anibal PC, Barbosa JP, Oliveira TR and Höfling JF* \\ Piracicaba Dental School, State University of Campinas, P.O. Box 52, 13414-903, Piracicaba, SP, Brazil.
}

Accepted 17 October, 2017

\begin{abstract}
Faced with increasing cases of antimicrobial resistance, new compounds from natural products have been scientifically investigated for their antibacterial and antifungalaction. Ethnopharmacological studies have shown that many plants extracts have been a source of new bioactive compounds acting against several types of diseases, attracting attention to researchers, aimed at their application in medicine. Studies were carried out with extracts from Punica granatum L. and its compounds have showed antioxidant, and antiinflammatory effects for the treatment of oral diseases, skin diseases, diarrhea, helminth infections, microbial infections and respiratory diseases among others. Its antimicrobial activity has been investigated recently, and may be present in various parts of the plant such as flowers, leaves, stems and bark. It was found high activity of the $P$. granatum methanolic extracts against strains of Bacillus subtilis, Staphylococcus aureus, Streptococcus epidermidis, Enterococcus faecalis, Escherichia coli, Candida albicans and other species. Candida yeast is an opportunistic pathogen and its virulence factors may contribute to its invasion and pathogenicity. These considerations served as a basis of the studies carried out in this review work, aiming to evaluate the use of extracts obtained from different parts of the $P$. granatum L. fruits as antimicrobial agents, associated to researches of components with bioactive potential present in these structures, determined by mass spectrometry.
\end{abstract}

Keywords: Punica granatum, extract, antifungal, Candida spp.

${ }^{*}$ Corresponding author. E-mail: hofling@fop.unicamp.br.

\section{INTRODUCTION}

Despite the successive advances in the use of drugs in the treatment of various diseases, a large part of the world population still depends on traditional medicine based on phytotherapy (Azaizeh et al., 2003). Knowledge about the medicinal use of plants and their properties have been transmitted from generation to generation (Lev and Amar, 2000), and ethnobotany is a very important area of study and knowledge around the world. This science shows a healthy relationship between humans and nature establishes the possibility of finding new uses for medicinal plants and can be used to discover new medicinal products derived from plants (Heinrich, 2000). For centuries, the bark, leaves, flowers and fruits of Punica granatum L. (Punicaceae), popularly known as pomegranate, have been used to treat diseases
(Gracious Ross et al., 2001). Studies with extracts from $P$. granatum and compounds had shown antioxidant effects (Ricci et al., 2006), antiinflammatory (Lansky and Newman, 2007), hepatoprotective (Celik et al., 2009) for the treatment of oral diseases (Fengchun et al., 1997), skin, among others (Hu, 1997). It was also used to treat acidosis, dysentery, microbial infections, diarrhea, helminthes, hemorrhage and respiratory pathologies (Fuentes and Exposito, 1995).

The antimicrobial activity of $P$. granatum has been investigated (Vasconcelos et al., 2003; Pereira et al., 2006b), and may be present in some metabolic toxins or broad spectrum antibiotic compounds contained in the bark (Voravuthikunchai et al., 2004). Duraipandiyan et al. (2006) found high activity of the pomegranate with the 
methanolic extract against the strains of Bacillus subtilis, Staphylococcus aureus, S. epidermidis, Enterococcus faecalis, Escherichia coli and Candida albicans. Braga et al. (2005) observed that the methanolic extract of the $P$. granatum fruits was able to inhibit not only the growth of Staphylococcus aureus FRI722, but also the production of enterotoxins. Höfling et al. (2010) found antifungal activity of pomegranate extracts against several species of Candida spp.

Candida yeast is an opportunistic pathogen and many virulence factors may contribute to its invasion and pathogenicity, as well as its ability to adhere to tissues, the conversion of its unicellular form to filamentous and expression of extracellular enzymes, such as aspartyl protease and phospholipases (Calderone and Fonzi, 2001).

Although $C$. albicans is the main isolated species of clinical specimens in AIDS patients, it is known that other non-albicans species such as C. glabrata, C. krusei, C. parapsilosis, C. tropicalis are highly prevalent in infections (Ruhnke, 2006). Candidiasis has re-emerged with a high mortality rate, with a prevalence of $45 \%$ in the groups of compromised patients (Wenzel and Gennings, 2005). Failure of the action of antifungals used in diseases caused by non-albicans species such as $C$. glabrata and $C$. krusei is now a therapeutic challenge. It is known that $C$. krusei infections are becoming prevalent due to the increase in the immunocompromised population, mainly with HIV (Human Immunodeficiency Virus) (Seneviratne et al., 2007), but it is also known that the resistance phenomenon of antimicrobial microorganisms is a fact to consider.

Microbial resistance is related to the loss of susceptibility of a microorganism to an antimicrobial agent which can be visualized by an in vitro susceptibility test in which the minimum inhibitory concentration is the lowest concentration of the drug which prevents visible growth of the microorganism (Alves et al., 1997; Marichal et al., 1999). Several antifungal drugs, such as fluconazole, ketoconazole, nystatin, amphotericin B, and 5 -fluorocytosine, may interfere with certain virulence factors (Ellepola and Samaranayake, 1998; Hazen et al., 2000), but emerging drug resistant strains have impeded antifungal treatment, often restoring the patient's health (Odds et al., 2003).

Research aiming at increasing knowledge about the antimicrobial potential for plants, particularly $P$. granatum, or its pharmacological components, relating the effects of its pharmaceutical properties to its antimicrobial activity, may contribute to its acceptance as an alternative medicine or to the allopathic treatment as a whole.

\section{LITERATURE REVIEW}

\section{Medicinal plants: Punica granatum}

The pomegranate, $P$. granatum $L$., has long been known for its edible fruit, being mentioned in the Bible and in the Alcoran, being associated with fertility. It is native to Persia and spread throughout Asia, North Africa and Mediterranean Europe, including Turkey. Pomegranate plantations in Turkey have grown rapidly in recent years, with production exceeding 100,000 tonnes in 2007 (Ozgen et al., 2008).

Pomegranate is known to be one of the healthiest fruits because of its high antioxidant activity (Gil et al., 2000; Aviram et al., 2008) and high content of anticarcinogenic compounds (Kim et al., 2002; Lansky et al., 2005; Malik et al., 2005; Adhami and Mukhtar, 2006; Malik and Mukhtar, 2006; Bell and Hawthorne, 2008). Folk medicine recommends both the stem and fruit peel to treat various diseases. The stem bark is used as a vermifuge, especially for tapeworms. From the fruit, dried or fresh peels are used for the treatment of diarrhea, skin and mucous infections and fresh seeds, with their pink and succulent wraps, for mouth and throat affections (Matos, 1989; Lansky et al., 1998).

Among the constituents present in the fruit of $P$. granatum $L$. are alkaloids (peletierina, methylpeletierina, pseudopeletierina and isopeletierina), manita, several phenols, ellagic acid and gallic acid. The peel of the pomegranate fruit contains alkaloids and approximately $20 \%$ of tannins, including punicalin, punicalagina, granatins $\mathrm{A}$ and $\mathrm{B}$, galagildylactone, casuarinina, pedunculagine, telimagrandin $\mathrm{I}$ and corilagina, with antibiotic action (Fetrow and Avila, 2000). It is popularly used in the treatment of sore throats, hoarseness and inflammation of the mouth. From the pericarp, rich in tannins, granatins $A$ and $B$, punicalagina and punicalin were isolated, being the main ones responsible for the antimicrobial activity (Catão et al., 2006).

Pomegranate is a rich source of phenolic compounds, which includes flavonoids and hydrolyzed tannins (Afaq et al., 2005). Extracts from different parts of the pomegranate fruit such as juice (Aviram et al., 2000), seeds (Singh et al., 2002; Wang et al., 2004) and bark (Singh et al., 2002; Lansky and Newman, 2007) have shown great antioxidant activity.

Monitoring the ethanolic extracts from $P$. granatum by mass spectrometry, Anibal et al. (2013) detected various compounds, among them delfinidin 3-O-glucoside, punicacortein $A$, punicacortein $B$, pedunculagin, tellimagrandin, glucose, citric acid, caffeic acid, punicic acid (cis-9, trans-11, cis-13 octadecatrienoic acid), ellagic acid, quercetin, delphinidin, gallagyldilacton and punicalagin from pericarp; and punicacortein $A$, punicacortein B, corilagin, glucose, citric acid, caffeic acid, punicic acid (cis-9, trans-11, cis-13 octadecatrienoic acid), pedunculagin, tellimagrandin and punicalagin from the peels.

\section{Phenolic compounds properties of $\boldsymbol{P}$. granatum}

The polyphenolic compounds comprise a group of the 
class of secondary plant metabolites, which act as antioxidants (Manach et al., 2005). Phenolic compounds are essential for plant growth and reproduction and are produced as a plant response to damage caused by pathogens. At low concentrations, they protect food from oxidative deterioration. At high concentrations, its oxidative product may interact with proteins, carbohydrates and minerals (Karakaya, 2004). Flavonoids made up one of the most numerous groups of phenolic compounds found in plants and fruits (Schinella et al., 2002; Tepe et al., 2005). Some of them are involved in the healing process of diseases caused by free radicals (Czinner et al., 2000). Many compounds of Punica granatum, such as alkaloids, flavonoids, polyphenols (such as delphinidin, cyanidin and pelargonidin) and hydrolyzable tannins, such as punicalin, pedunculagine, punicalagin, gallic acid and ellagic acid (glucose esters) have strong antioxidant properties and have been investigated (Du et al., 1975; Tzulker et al., 2007). Anthocyanins, belonging to the family of flavonoids biosynthesized from the phenylpropanoid pathway, constitute an important class of polyphenols (Saviranta et al., 2008). They are composed of mixed biosynthesis, involving blocks of the polyacetate pathway and the chiquimato pathway (Lobo and Lourenço, 2007). Duman et al. (2009) correlated that the large amount of anthocyanins presents in the pomegranate juice exerted high antibacterial and antifungal activity in the tests performed due to its antioxidant capacity. This class of compounds has demonstrated antioxidant, anti-inflammatory, antiatherosclerotic and anticancer activities in several studies (Kong et al., 2003a; Zafra-Stone et al., 2007; Srivastava et al., 2007). The common form of aglycone, anthocyanidin, found is cyanidin, delphinidin, peonidine, petunidine, malvidin and pelargonidin. Chemical analyzes performed by Dudonné et al. (2009) showed that the phenolic compounds of pomegranate contain high levels of hydrolysable tannins, such as punicalina, punicalagina, pedunculagina and punigluconina.

The complexation between tannins and proteins is the basis for their properties as factors controlling insects, fungi and bacteria as well as for their pharmacological activities (Simões et al., 2007), and may act as inhibitors of reverse transcriptase and HIV (Kilkuskie et al., 1992).

In vitro tests performed with extracts rich in tannins or with pure tannins have identified several biological activities of this class of substances. Among these we can mention: bactericidal and fungicidal action (Scalbert, 1991; Chung et al., 1998c), antiviral (Okuda et al., 1993; De Bruyne et al., 1999b), inhibition of enzymes such as glycosyltransferases from Streptococuus mutans and $S$. sobrinus (Hattori et al., 1990; Ooshima et al., 1993), inhibition of lipid peroxidation and free radical scavenger (Hagerman et al., 1998; Moure et al., 2001) and antitumor action (Wang et al., 1999; Dufresne and Farnworth, 2001).
A number of bacteria are sensitive to tannins, among them Staphylococcus aureus, Streptococcus pneumoniae, Bacillus anthracis and Shigella dysenteriae. There are three hypotheses for the mechanism of antimicrobial action. The first hypothesis assumes the inhibition of bacterial and fungal enzymes and/or the complexation of the substrates of these enzymes; the second would be the action of tannins on the cell membranes of microorganisms, modifying their metabolism. Finally, the third hypothesis mentions the complexation of tannins with metal ions (Mila et al., 1996), thus reducing the availability of these essential elements for the metabolism of microorganisms (Simões et al., 2007).

Elsherbiny et al. (2016) worked with the methanol extract of pomegranate peels demonstrating inhibition on mycelial growth of Fusarium sambucinum and a complete inhibition on spore germination using this extract. Twenty four individual phenolic compounds were identified and quantified in the extract using HPLC analysis, with the total phenol content as $104.6 \mathrm{mg} \mathrm{GAE} / \mathrm{g}$ extract according to the Folin-Ciocalteu method.

Polyphenols are hydrolyzable phytochemicals and the more hydrophilic the extractive solvent the better those compounds will be recovered from the plant (Negi and Jayaprakasha, 2003; Alzoreky and Nakahara, 2003). The mechanism responsible for the toxicity of the phenolic compound against microorganisms may be in the reaction with the sulfhydryl groups and substrates of the microorganism, interfering with the bacterial protein secretion (Machado et al., 2003; Naz et al., 2007).

\section{Yeasts of the genus Candida}

Candida spp. are yeasts that normally present as individual cells and reproduce asexually by budding. Candida albicans is a polymorphic diploid yeast with eight pairs of chromosomes. It can replicate under anaerobic conditions, as in the intestine (Kruppa, 2008). Almost 200 species of Candida are known, but only a few are important to man. The most important are $C$. albicans, $C$. glabrata, C. krusei, C. dubliniensis, C. tropicalis, C. parapsilosis, C. guilliermondii and C. lusitaniae (Bernhardt and Knoke, 1997; Calderone, 2002; Hube, 2004).

Several factors, such as adhesion to host tissue, morphological characteristics, germ tube formation, contact perception, phenotypic change, synergism with bacteria, production of hydrolases or other metabolites, and production of extracellular enzymes were proposed as virulence factors of C. albicans (Odds, 1988; Olsen 1990; Bendel, 2003). Adherence of yeast to host mucosal surfaces is a prerequisite for colonization and infection (Olsen, 1990; Bendel, 2003). Mucous host surfaces serve as a reservoir for the spread of infections, such as gastrointestinal infection, especially in immune- 
compromised patients (Nikawa et al., 2006). During the early stages of superficial mucosal infection, C. albicans forms filamentous hyphae (Sherwood et al., 1992; Gow et al., 1994), along with the release of various hydrolytic enzymes (Ruechel, 1990). Its hyphae have ability to penetrate into the host tissue, adhering to a much greater extent when compared to the cellular form. Thus, hyphae are an important instrument for the attack and the infectious process (Järvensivu et al., 2004). In the United States, yeast infection is classified as the fourth most common cause of nosocomial blood infection (Wisplinghoff et al., 2004). In Brazil, Candida albicans, C. tropicalis and $C$. parapsilosis are the most common species isolated from blood-to-colon infection in several medical centers (Colombo et al., 2006; Medrano et al., 2006; Passos et al., 2007).

\section{Resistance to antifungal agents}

The occurrence of systemic fungal infections has increased, along with the growing number of immunocompromised individuals whose population increases in parallel due to the AIDS pandemic, cancer chemotherapy treatment and organ transplantation. Among these populations, especially those infected with HIV, fluconazole doses are generally given prophylactically to prevent the occurrence of opportunistic fungal infections. Thus, prolonged treatments results from the appearance of $C$. albicans phenotypes resistant to azole antifungals (White et al., 1998; Kontoyiannis and Lewis, 2002). Oropharyngeal candidiasis along with antifungal cross-resistance is one of the major problems faced by HIV-positive patients (Vanden Bossche et al., 1994). Immunosuppressed patients are at high risk of infection with resistant organisms, as well as patients who had exposure to high doses of fluconazole $(>10 \mathrm{~g})$, or treatment with long duration (Maenza et al., 1996).

Several investigations suggest that resistance to fluconazole may be induced in patients who are under a prolonged period of treatment (Ruhnke et al., 2000).

The wide use of itraconazole and fluconazole is considered the main cause of resistance to azoles (Goldman et al., 2000). Invasive candidiasis is an important cause of complications and death in hospitalized patients. Amphotericin B has been used as standard treatment for five decades, but its toxic effects have limited its use (Rex et al., 1994). However, some species of Candida, such as C. krusei and C. glabrata, are frequently resistant to fluconazole. This fact and the fungistatic activity of triazoles constitute the main limitations of fluconazole as the first line in the therapy for candidemia. Increased prevalence of microbial resistance to commercial antifungal drugs has been observed. The low therapeutic efficacy observed in some infections may be due to the inefficient penetration of the drugs into the infected cells, not allowing the drug to reach the yeast
(Drago et al., 2000). All these aspects make the demand for new antimicrobial compounds important, including those that may be present in plant extracts (Filoche et al., 2005).

\section{Extracts of $P$. granatum activity on Candida spp.}

With the increasing development of drug resistance and the appearance of undesirable effects by antifungal agents, research on new antimicrobial components has been a concern of many researchers (Phongpaichit et al., 2005). Bioactive compounds have been isolated and subjected to detailed structural analyzes, and their mode of action and target known (Ishida et al., 2006). The discovery of drugs involving the diversity of natural products, combined with synthetic drug methodologies and including the manipulation of biosynthetic pathways, provides a solution to the scientific community focused on the discovery and development of drugs (Newman and Cragg, 2007).

When analyzed the extract from the pomegranate in the inhibition of yeasts of the genus Candida, several works show activity of this plant, as demonstrated by Navarro et al. (1996), Vasconcelos et al. (2003), Duraipandiyan et al. (2006), Vasconcelos et al. (2006), Reddy et al. (2007), Al-Zoreky (2009) and Duman et al. (2009). Anibal (2007) evaluated the activity of the pomegranate through crude extracts dichloromethane and methanolic, against standard strains of $C$. albicans, C. glabrata, C. krusei, C. parapsilosis, C. tropicalis, C. dubliniensis, C. utilis, C. guilliermondii, C. lusitaniae, and C. rugosa, demonstrating antifungal activity of this plant of interest for alternative therapy against these microorganisms.

Anibal et al. (2013) showed that ethanolic extracts obtained from pericarp and peel presented potential inhibitory activity, with a minimun inhibitory concentration of $125 \mu \mathrm{g} / \mathrm{ml}$. These data indicate that the activity of $P$. granatum probably occurs in the compounds present in the pericarp and peel of this fruit. The samples of pericarp and peel extract, that presented better results against Candida species, had a high concentration of the punicalagin compound as a differential, in addition to other tannins, such as pedunculagin and tellimagrandin. Therefore, punicalagin and gallagyldilacton are apparently the major compounds involved in antifungal activity observed in the extracts of $P$. granatum.

Catão et al. (2006) and Fetrow and Avila (2000) indicated tannins, such as punicalin, punicalagin, gallagyldilacton, pedunculagin, tellimagrandin I and corilagin, to be responsible for the antimicrobial activity. Endo et al. (2010) observed elevated activity of the isolated compound punicalagin against $C$. albicans and C. parapsilosis, indicating this substance as a potent antifungal agent, without however, elucidating the mechanism of action. Vasconcelos et al. (2003) assigns 
to the tannins, the ability to inhibit the growth of yeast Candida species due to their actions in the cell, specifically in the cell membrane, precipitating proteins.

\section{DISCUSSION}

The plant kingdom represents a large reservoir of pharmacologically active molecules to be discovered, and study containing many different secondary metabolites involving the active principle has become a promising field for the discovery of new phytomedicines as an alternative treatment of diseases (whether they are caused by bacteria or fungi). In the literature there are several studies showing, in particular, antimicrobial and antifungal effects on microorganisms of medical interest, as well as having a significant treatment in resistant strains and not causing such dangerous side effects for the health; justifying the researches with purposes of evaluating the antimicrobial potential of these phytotherapics. As can be seen in this review, pomegranate has antimicrobial compounds that make this plant a promising alternative for treatment of diseases.

Such plant has many kinds of properties and biocomponents from its secondary metabolites, as alkaloids and polyphenolic compounds, involving antimicrobial properties. Several studies had been showed effects against many bacteria and yeasts, especially against Candida spp., that has increased the infections on groups of compromised patients with the increasing development of drug resistance and the appearance of undesirable effects by antifungal agents.

The discovery of drugs involving the diversity of natural products, combined with synthetic drug methodologies and the manipulation of biosynthetic pathways, provides an alternative solution to the scientific community focused on the discovery and development of drugs, making the pomegranate a potential plant alternative for treatment of diseases.

\section{REFERENCES}

Adhami V, Mukhtar H, 2006. Polyphenols from green tea and pomegranate for prevention of prostate cancer. Free Rad Res, 40: 1095-1104.

Afaq F, Saleem M, Krueger CG, Reed JD, Mukhtar H, 2005. Anthocyanin- and hydrolyzable tannin-rich pomegranate fruit extract modulates MAPK and NFkappa B pathways and inhibits skin tumorigenesis in CD-1 mice. Int J Cancer, 113: 423-433.

Alves SH, Lopes JO, Costa JM, Klock C, 1997. Development of secondary resistance to fluconazole in Cryptococcus neoformans isolated from a patient with AIDS. Revista do Instituto de Medicina Tropical de São Paulo, 39: 359-361.

Al-Zoreky NS, 2009. Antimicrobial activity of pomegranate (Punica granatum L.) fruit peels. Int J Food Microbiol, 134: 244-248.

Anibal PC, 2007. Potencial de ação antimicrobiana in vitro de extratos brutos de plantas na inibição de Candida spp, Streptococcus mutans e Staphylococcus aureus. Dissertação (Mestrado - Área de Concentração em Microbiologia e Imunologia). Departamento de
Diagnóstico Oral, Faculdade de Odontologia de Piracicaba: UNICAMP/FOP, Piracicaba. 83p.

Anibal PC, Peixoto ITA, Foglio MA, Höfling JF, 2013. Antifungal activity of the ethanolic extracts of Punica granatum $L$. and evalution of morphological and structural modifications of its compounds upon the cells of Candida spp. Braz J Microbiol, 44(3): 839-848.

Aviram M, Dornfeld L, Rosenbalt M, Volkova N, Kaplan M, Coleman R, Hayek T, Presser D, Fuhrman B, 2000. Pomegranate juice consumption reduces oxidative stress, atherogenic modifications to LDL, and platelet aggregation: studies in humans and in atherosclerotic apolipoprotein E-deficient mice. Am J Clin Nutr, 71: 1062-1076.

Aviram M, Volkova N, Coleman R, Dreher M, Reddy MK, Ferreira D, Rosenblat M, 2008. Pomegranate phenolics from the peels, arils, and flowers are antiatherogenic: Studies in vivo in atherosclerotic apolipoprotein E-deficient (E0) mice and in vitro in cultured macrophages and lipoproteins. J Agric Food Chem, 56: 1148-1157.

Azaizeh H, Fulder S, Khalil K, Said O, 2003. Ethnomedicinal knowledge of local Arab practitioners in the Middle East Region. Fitoterapia, 74: 98-108.

Bell C, Hawthorne S, 2008. Ellagic acid, pomegranate and prostate cancer-a mini review. J Pharm Pharmacol, 60: 139-144.

Bendel CM, 2003. Colonization and epithelial adhesion in the pathogenesis of neonatal candidiasis. Seminar Perinatol, 27: 357364.

Bernhardt H, Knoke M, 1997. Mycological aspects of gastrointestinal microflora. Scand J Gastroenterol, 32(Suppl 222): 102-106.

Braga LC, Shupp JW, Cummings C, Jett M, Takahashi JA, Carmo LS, Chartone-Souza E, Nascimento AM, 2005. Pomegranate extract inhibits Staphylococcus aureus growth and subsequent enteroxin production. J Ethnopharmacol, 96: 335-339.

Calderone RA, 2002. Taxonomy and biology of Candida. In: Calderone RA (ed.): Candida and Candidiasis. Washington: ASM Press. p. 1527.

Calderone RA, Fonzi WA, 2001. Virulence factors of Candida albicans. Trends Microbiol, 9(7):327-35.

Catão RMR, Antunes RMO, Arruda TA, Pereira MSV, Higino JS, Alves JA, Passos MGVM, Santos VL, 2006. Atividade antimicrobiana in vitro do extrato etanólico de Punica granatum Linn. (romã) sobre isolados ambulatoriais de Staphylococcus aureus. Rev Bras Anal Clin 38:111-114.

Celik I, Temur A, Isik I, 2009. Hepatoprotective role and antioxidant capacity of pomegranate (Punica granatum) flowers infusion against trichloroacetic acid-exposed in rats. Food Chem Toxicol, 47: 145-149.

Chung KT, Lu Z, Chou MW, 1998c. Mechanism of inhibition of tannic acid and related compounds on the growth of intestinal bacteria Food Chem Toxicol, 36: 1053-1060.

Colombo AL, Nucci M, Park BJ, Nouér SA, Arthington-Skaggs B, da Matta DA, Warnock D, Morgan J, Brazilian Network Candidemia Study, 2006. Epidemiology of candidemia in Brazil: a nationwide sentinel surveillance of candidemia in eleven medical centers. J Clin Microbiol, 44: 2816-2823.

Czinner E, Hagymasi K, Blazovics A, Kery A, Szoke E, Lemberkovics E, 2000. In vitro antioxidant properties of Helichrysum arenarium (L) Moench. J Ethnopharmacol, 73: 437-443.

De Bruyne T, Pieters L, Witvrouw M, De Clercqe, Berghe DV, Vlietinck AJ, 1999b. Biological evalution of proanthocyanidins and related polyphenols. J Nat Prod, 62: 954-958.

Drago L, Mombelli B, Vecchi ED, Bonaccorso C, Fassina MC, Gismondo MR, 2000. Candida albicans cellular internalization: a new pathogenic factor? Int J Antimicrob Agents, 16: 545-547.

Du CT, Wang PL, Francis FJ, 1975. Anthocyanins of pomegranate, Punica granatum. J Food Sci, 40: 417-418.

Dudonné S, Vitrac X, Coutiere P, Woillez M, Merillon JM, 2009. Comparative study of antioxidant properties and total phenolic content of 30 plant extracts of industrial interest using DPPH, ABTS, FRAP, SOD, and ORAC assays. J Agric Food Chem, 57: 1768-1774.

Dufresne CJ, Farnworth ER, 2001. A review of latest research findings on health promotion properties of tea. J Nutr Biochem, 12: 404-421.

Duman AD, Ozgen M, Dayisoylu KS, Erbil N, Durgac C, 2009. Antimicrobial activity of six pomegranate (Punica granatum L.) varieties and their relation to some of their pomological and 
phytonutrient characteristics. Molecules, 14: 1808-1817.

Duraipandiyan V, Ayyanar M, Ignacimuthu S, 2006. Antimicrobial activity of some ethnomedicinal plants used by Paliyar tribe from Tamil Nadu, India. BMC Complement Alternat Med, 6: 1-7.

Ellepola ANB, Samaranayake LP, 1998. The effect of limited exposure to antimycotics on the relative cell surface hydrophobicity and the adhesion of oral Candida albicans to buccal epithelial cells. Arch Oral Biol, 43: 879-887.

Elsherbiny $\mathrm{AE}$, Amin BH, Baka ZA, 2016. Efficiency of pomegranate (Punica granatum L.) peels extract as a high potential natural tool towards Fusarium dry rot on potato tubers. Postharvest Biol Technol, 111: 256-263.

Endo EH, Cortez DAG, Ueda-Nakamura T, Nakamura CV, Dias Filho BP, 2010. Potent antifungal activity of extracts and pure compound isolated from pomegranate peels and synergism with fluconazole against Candida albicans. Res Microbiol, 161: 534-540.

Fengchun $\mathrm{H}$, Liu X, Chen $\mathrm{H}, 1997$. Medicine for treatment of infectious oral diseases. Chinese Patent 1145793A.

Fetrow CW, Avila JR, 2000. Manual de medicina alternativa para 0 profissional. Rio de Janeiro: Ed. Guanabara Koogan. p. 590-592.

Filoche SK, Soma K, Sissons $\mathrm{CH}$, 2005. Antimicrobial effects of essential oils in combination with chlorhexidine digluconate. Oral Microbiol Immunol, 20: 221-225.

Fuentes VR, Exposito A, 1995. Las encuestas etnobotanicas sobre plantas medicinales en Cuba. Revista Jarder Bo Nacion Univ Habana, 16: 77-144.

Gil MI, Tomas-Barberan FA, Hess-Pierce B, Holcroft DM, Kader AA, 2000. Antioxidant activity of pomegranate juice and its relationship with phenolic composition and processing. J Agric Food Chem, 48: 4581-4589.

Goldman M, Cloud GA, Smedema M, Lemonte A, Connolly P, Mckinsey DS, Kauffman CA, Moskovitz B, Wheat LJ, 2000. Does long-term itraconazole prophylaxis result in in vitro azole resistance in mucosal Candida albicans isolates from persons with advanced human immunodeficiency virus infection? The National Institute of Allergy and Infectious Diseases Mycoses study group. Antimicrob Agents Chemother, 44: 1585-1587.

Gow NA, Perera THS, Sherwood-Hingham GW, Gregory DW, Marshall D, 1994. Investigation of touch sensitive responses by hyphae of the human pathogenic fungus Candida albicans. Scanning Microscopy, 8: 705-710.

Gracious Ross R, Selvasubramanian S, Jayasunder S, 2001. Immunomodulatory actvity of Punica granatum in rabbits - a preliminary study. Journal of Ethnopharmacology, 78: 85-87.

Hagerman AE, Riedl KM, Jones AG, Sovik KN, Ritchard NT, Hartzfeld PW, Riechel TL, 1998. High molecular weight plants polyphenolics (tannins) as biological antioxidants. J Agric Food Chem, 46: 18871892.

Hattori M, Kusumoto LT, Namba T, Ishigami T, Hara Y, 1990. Effect of tea polyphenols on glucan synthesis by glucosyl transferase from Streptococcus mutans. Chem Pharmaceut Bull, 38: 717-720.

Hazen KC, Mandell G, Coleman E, Wu G, 2000. Influence of fluconazole at inhibitory concentrations on cell surface hidrophobicity and phagocytosis of Candida albicans. FEMS Microbiol Lett, 183: 8994.

Heinrich M, 2000. Ethnobotany and its role in drug development. Phytother Res, 14: 479-88.

Höfling JF, Anibal PC, Obando-Pereda GA, Peixoto IAT, Furletti VF, Foglio MA, Gonçalves RB, 2010. Antimicrobial potential of some plant extracts against Candida species. Braz J Biol, 70(4):1065-1068.

Hu W, 1997. Skin health inflammatory inucta and producing process thereof. Chinese Patent 1156617A.

Hube B, 2004. From commensal to pathogen: stage- and tissue-specific gene expression of Candida albicans. Curr Opin Microbiol, 7: 336341.

Ishida K, Mello JCP, Cortez DAG, Filho BPD, Ueda-Nakamura T, Nakamura CV, 2006. Influence of tannins from Stryphnodendron adstrngens on growth and virulence factors of Candida albicans. J Antimicrob Chemother, 58: 942-949.

Järvensivu A, Hietanen J, Rautemaa R, Sorsa T, Richardson M, 2004. Candida yeasts in chronic periodontitis tissues and subgingival microbial biofilms in vivo. Oral Dis, 10: 106-112.
Karakaya S, 2004. Bioavailability of phenolic compounds. Crit Rev Food Sci Nutr, 44: 453-464.

Kilkuskie RE, Kashiwada Y, Nonaka G, Nishioka I, Bodner A, Cheng Y, Lee $\mathrm{KH}$, 1992. HIV and reverse transcriptase inhibition by tannins. Bioorg Med Chem Lett, 2: 1529-1534.

Kim ND, Mehta R, Yu W, Neeman I, Livney T, Amichay A, Poirier D, Nicholls P, Kirby A, Jiang W, Mansel R, Ramachandran C, Rabi T, Kaplan B, Lansky E, 2002. Chemopreventive and adjuvant therapeutic potential of pomegranate (Punica granatum) for human breast cancer. Breast Cancer Res Treatment, 71: 203-217.

Kong JM, Khang NK, Chia LS, Chia TF, 2003a. Recent advances in traditional plant drugs and orchids. Acta Pharmacol Singapore, 24: 721.

Kontoyiannis DP, Lewis RE, 2002. Antifungal drug resistance of pathogenic fungi. Lancet, 359: 1135-1144.

Kruppa M, 2008. Quorum sensing and Candida albicans. Mycoses, 52: 1-10.

Kulkarni AP, Aradhya MS, 2005. Chemical changes and antioxidant activity in pomegranate arils during fruit development. Food Chem, 93: 319-324.

Lansky E, Shubert S, Neeman I, 1998. Pharmacological and therapeutic properties of pomegranate. Symposium International Sobre El Granado (First International Symposium on the Pomegranate), Orihuela, Spain, Oct. 15-17.

Lansky EP, Jiang W, Mo H, Bravo L, Froom P, Yu W, Harris NM, Neeman I, Campbell MJ, 2005. Possible synergistic prostate cancer suppression by anatomically discrete pomegranate fractions. Invest New Drugs, 23: 11-20.

Lansky EP, Newman RA, 2007. Punica granatum (pomegranate) and its potential for prevention and treatment of inflammation and cancer. J Ethnopharmacol, 109: 177-206.

Lev E, Amar Z, 2000. Ethnopharamcological survey of traditional drugs sold in Israel at the end of 20th century. J Ethnopharmacol, 72: 191205.

Lobo AM, Lourenço AM, 2007. Biossíntese de produtos naturais. IST Pess, Lisboa: Portugal. $272 \mathrm{p}$.

Maenza JR, Keruly JC, Moore RD, Chaisson RE, Merz WG, Gallant JE, 1996. Risk factors of fluconazole-resitance candidiasis in human immunodeficiency virus-infected patients. J Infect Dis, 173: 219-225.

Malik A, Afaq F, Sarfaraz S, Adhami VM, Syed DN, Mukhtar H, 2005. Pomegranate fruit juice for chemoprevention and chemotherapy of prostate cancer. Proc Natl Acad Sci USA, 102: 14813-14818.

Malik A, Mukhtar $\mathrm{H}$, 2006. Prostate cancer prevention through pomegranate fruit. Cell Cycle, 5: 371-373.

Manach C, Williamson G, Morand C, Scalbert A, Remesy C, 2005. Bioavailability and bioefficacy of polyphenols in humans. I. Review of 97 bioavailability studies. Am J Clin Nutr, 81: 230S-242S.

Marichal P, Koymans L, Willemsens S, Bellens D, Verhasselt P, Luyten W, Borgers M, Ramaekers FC, Odds FC, Bossche HV, 1999. Contribution of mutations in the cytochrome P450 14alphademethylase (Erg11p, Cyp51p) to azole resistance in Candida albicans. Microbiology, 145(Pt 10): 2701-2713.

Matos FJA, 1989. Plantas medicinais: guia de seleção e emprego de plantas usadas em fitoterapia no nordeste do Brasil. Fortaleza: IOCE, 2: $74-75$.

Medrano DJ, Brilhante RS, Cordeiro AR, Rocha MF, Rabenhorst SH, Sidrim JJ, 2006. Candidemia in a Brazilian hospital: the importance of Candida parapsilosis. Revista do Instituto de Medicina Tropical de São Paulo, 48: 17-20.

Mila I, Scalbert A, Expert D, 1996. Iron withholding by plant opolyphenols and resistance to pathogerns and rots. Phytochemistry, 42: 1551-1555.

Moure A, Cruz JM, Franco D, Dominguez JM, Sinero J, Dominguez $\mathrm{H}$, Núñez MJ, Parajóa JC, 2001. Natural antioxidants from residual sources. Food Chem, 72: 145-171.

Navarro V, Villarreal ML, Rojas G, Lozoya X, 1996. Antimicrobial evaluation of some plants used in Mexican traditional medicine for the treatment of infectious diseases. J Ethnopharmacol, 53: 143-147.

Naz S, Siddiqi R, Ahmad S, Rasool S, Sayeed S, 2007. Antibacterial activity directed isolation of compounds from Punica granatum. J Food Sci, 72: 341-345.

Newman DJ, Cragg GM, 2007. Natural products as source of new 
drugs over the last 25 years. J Nat Prod, 70: 461-477.

Nikawa $H$, Egusa $H$, Makihira $S$, Okamoto $T$, Kurihara $H$, Shiba $H$, Amano $\mathrm{H}$, Murayama $\mathrm{T}$, Yatani $\mathrm{H}$, Hamada $\mathrm{T}$, 2006. An in vitro evaluation of the adhesion of Candida species to oral and lung tissue cells. Mycoses, 49: 14-17.

Odds FC, 1988. Candida and candidiasis. 2nd Edn. London, England: Bailliere, Tindall.

Odds FC, Brown AJ, Gom NA, 2003. Antifungal agents: mechanism of action. Trends Microbiol, 11:272-279.

Okuda T, Yoshida T, Hatano T, 1993. Classification of oligomeric hydrolysable tannins and specificity of their occurrence in plants. Phytochemistry, 32: 507-521.

Olsen I, 1990. Oral adhesion of yeast. Acta Odontologica Scandinavica, 48: 39-53.

Ooshima T, Minami T, Aono W, Izumatani A, Sobue S, Fujiwara T, Kawabata S, Hamada S, 1993. Oolong tea polyphenols inhibit experimental dental caries in SPF rats infected with Streptococcus mutans. Caries Res, 27: 124-129.

Ozgen M, Durgac C, Serce S, Kaya C, 2008. Chemical and antioxidant properties of pomegranate cultivars grown in mediterranean region of Turkey. Food Chem, 111: 703-706.

Passos XS, Costa CR, Araújo CR, Nascimento ES, Souza LK, Fernandes OF, Sales WS, Silva MR, 2007. Species distribution and antifungal susceptibility patterns of Candida spp. bloodstream isolates from a Brazilian tertiary care hospital. Mycopathologia, 163: 145-151.

Pereira JV, Pereira MSV, Sampaio FC, Sampaio MCC, Alves PM, Araújo CRF, Higino JS, 2006b. In vitro antibacterial and antiadherence effect of Punica granatum Linn extracts upon dental biofilm microorganisms. Braz J Pharmacog, 16: 88-93.

Phongpaichit S, Subhadhirasakul S, Wattanapiromsakul C, 2005. Antifungal activities of extracts from Thai medicinal plants against opportunistic fungal pathogens associated with AIDS patients. Mycoses, 48: 333-338.

Reddy MK, Gupta SK, Jacob MR, Khan SI, Ferreira D, 2007. Antioxidant, antimalarial and antimicrobial activities of tannin-rich fractions, ellagitannins and phenolic acids from Punica granatum $\mathrm{L}$. Planta Medica, 73: 461-467.

Rex JH, Bennet JE, Sugar AM, Pappas PG, Van Der Horst CM, Edwards JE, Washburn RG, Scheld WM, Karchmer AW, Dine AP, 1994. A randomized trial comparing fluconazole with amphotericin $B$ for the treatment of candidaemia in patients without neutropenia. New Engl J Med, 331: 1325-1330.

Ricci D, Giamperi L, Bucchini A, Fraternale D, 2006. Antioxidant activity of Punica granatum fruits. Fitoterapia, 77: 310-312.

Ruechel R, 1990. Virulence factors of Candida species. In: Samaranayake LP, Macfarlane TW, eds. Oral candidosis. London, England: Butterworth and Co. (Publishers) Ltd. p. 47-65.

Ruhnke M, 2006. Epidemiology of Candida albicans infections and role of non-Candida-albicans yeasts. Curr Drug Targets, 7: 495-504.

Ruhnke M, Schmidt-Westhausen A, Morschhauser J, 2000. Development of resistance to fluconazole in Candida albicans and Candida dubliniensis in a patient with AIDS. J Antimicrobial Chemother, 46: 291-295.

Saviranta NM, Anttonen MJ, Von Wright A, Karjalainen RO, 2008. Red clover (Trifolium pretense L.) isoflavones: determination of concentrations by plant stage, flower colour, plant part and cultivar. J Sci Food Agric, 88: 125-132.

Scalbert A, 1991. Antimicrobial properties of tannins. Phytochemistry, 30: 3875-3883.

Schinella GR, Tournier HA, Prieto JM, Mordujovich de Buschiazzo P, Rios JL, 2002. Antioxidant activity of anti-inflammatory plant extracts. Life Sci, 70: 1023-1033.

Seneviratne CJ, Wong RWK, Samaranayake LP, 2007. Potent antimicrobial activity of traditional Chinese medicine herbs against Candida species. Mycoses, 51: 30-34.

Sherwood J, Gow NA, Gooday GW, Gregory DW, 1992. Contact sensing in Candida albicans: a possible aid to epithelial penetration. J Med Vet Mycol, 32: 439-447.
Simões CMO, Schenkel EP, Gosmann G, Mello JCP, Mentz LA Petrovick PR, 2007. Farmacognosia: da planta ao medicamento. Florianópolis: Editora da UFSC / Porto Alegre: Editora da UFRGS, 6 Ed. p. 577-584.

Singh RP, Murthy KNC, Jayaprakasha GK, 2002. Studies on the antioxidant activity of pomegranate (Punica granatum) peel and seed extracts using in vitro models. J Agric Food Chem, 50: 81-86.

Srivastava A, Akoh CC, Fischer J, Krewer G, 2007. Effect of anthocyanin fractions from selected cultivars of Georgia - grown blueberries on apoptosis and phase II enzymes. J Agric Food Chem, 55: 3180-3185.

Tepe B, Sokmen M, Akpulat AH, Sokemen A, 2005. In vitro antioxidant activities of the methanol extracts of four Helichrysum species from Turkey. Food Chem, 90: 685-689.

Tzulker R, Glazer I, Bar-llan I, Holland D, Aviram M, Amir R, 2007. Antioxidant activity, polyphenol content and related compounds in different fruit juices and homogenates prepared from 29 different pomegranate accessions. J Agric Food Chem, 55: 9559-9570.

Vanden Bossche $H$, Marichal P, Odds FC, 1994. Molecular mechanisms of drug resistance in fungi. Trend Microbiol, 2: 393-400.

Vasconcelos LC, Sampaio FC, Sampaio MC, Pereira MS, Higino JS, Peixoto $\mathrm{MH}, 2006$. Minimum inhibitory concentration of adherence of Punica granatum Linn (pomegranate) gel against S. mutans, S. mitis and C. albicans. Braz Dental J, 17: 223-227.

Vasconcelos LCS, Sampaio MCC, Sampaio FC, Higino JS, 2003. Use of Punica granatum Linn as an antifungal agent against candidosis associated with denture stomatitis. Mycoses, 46: 192-196.

Voravuthikunchai S, Lortheeranuwat A, Jeeju W, Sririrak T, Phongpaichit S, Supawita T, 2004. Effective medicinal plants against enterohaemorrhagica Escherichia coli O157:H7. J Ethnopharmacol, 94: 49-54.

Wang CC, Chen LG, Yang LL, 1999. Antitumor activity of four macrocyclic ellagitannins from Cuphea hyssopifolia. Cancer Lett, 140: 195-200.

Wang RF, Xie WD, Zhang Z, Xing DM, Ding Y, Wang W, Ma C, Du LJ, 2004. Bioactive compounds from the seeds of Punica granatum (pomegranate). J Nat Prod, 67: 2096-2098.

Wenzel RP, Gennings C, 2005. Bloodstream infections due to Candida species in the intensive care unit: identifying especially high-risk patients to determine prevention strategies. Clin Infect Dis, 41(Suppl 6): 389-393.

White TC, Marr KA, Bowden RA, 1998. Clinical, cellular, and molecular factors that contribute to antifungal drug resistance. Clin Microbiol Rev, 11: 382-402.

Wisplinghoff $\mathrm{H}$, Bischoff $\mathrm{T}$, Tallent SM, Seifert $\mathrm{H}$, Wenzel RP, Edmond MB, 2004. Nosocomial bloodstream infections in US hospitals: analysis of 24,179 cases from a prospective nationwide surveillance study. Clin Infect Dis, 39: 309-317.

Zafra-Stone S, Yasmin T, Bagchi M, Chatterjee A, Vinson JA, Bagchi $D, 2007$. Berry anthocyanins as novel antioxidants in human health and disease prevention. Mol Nutr Food Res, 51: 675-683.

Citation: Anibal PC, Barbosa JP, Oliveira TR, Höfling JF, 2017. The chemical composition and inhibitory action of Punica granatum (L.) extracts against Candida spp.: A brief review. Adv Med Plant Res, 5(4): 68-74. 